\title{
適切な技能伝承の進め方を定量的に選択する手法に関する研究* （技能伝承過程における生産プロセスのシミュレーションによる再設計）
}

\author{
鈴木 陽一郎 ${ }^{* 1}$ ，小山 秀夫*2，金 㕍 $^{* 3}$
}

\section{A study on the quantitative method for choosing an appropriate skill developing strategy (A simulation based manufacturing process redesign for skill developing)}

\author{
Yoichiro SUZUKI*1 , Hideo KOYAMA and Yan JIN \\ ${ }^{* 1}$ Japan Marine Science Inc. \\ Solid Square West 3F, 580 Horikawa-cho, Saiwai-ku, Kawasaki, Kanagawa, 212-0013 Japan
}

\section{Received 21 October 2013}

\begin{abstract}
Planning human resource procurement, as well as planning cost, quality and capacity of production, is one of the crucial issues for enterprises in order to achieve the target sales and profit. For the planning, two issues should be addressed. First is how to transfer the necessary skills and knowledge, which is in the educational perspective and many studies and methodologies have been achieved in respect to the issue. Second is how to change the production processes where the human resources are allocated considering the effect of the design on the production capacity, cost and quality of the target processes along the human resource procurement schedule, which is in the management perspective. This paper focuses on the second issue. For instance, procuring and training many resources can minimized the human resource procurement schedule. It, however, might increase the quality and cost risks of the target production processes. Contrarily, gradually procuring and training human resources might reduces the quality and cost risks. It, however, increases the procurement schedule and risks of the opportunity loss. The strategies for procuring the necessary human resources are varied by the requirements to the management based on the enterprise strategy and surrounding market demands. In this paper, we applied the simulation based process evaluation methodology for quantitatively choosing the human resource procurement strategy appropriate to the management requirements. Firstly, we predicted the process performances in respect to the available human resources with our developing simulation tool. Secondary, we estimated the changes of process performances along the various human procurement strategies. Finally, we demonstrated how to choose a human resource procurement strategy appropriate to the management requirements.
\end{abstract}

Key Words : Human resource procurement strategy, Management perspective, Process changes, Process performances, Simulation based prediction, Quantitatively choosing

\section{1. 緒言}

\section{$1 \cdot 1$ 研究の目的}

技能伝承は, 企業にとっては古くて新しい永遠のテーマで, 生産現場においては常に重要な問題の一つである. 例えば 2007 年問題は，企業にとって無形の資産又は資本としての技能・技術を有する団塊世代が，定年により大 量に退職することにより生じる技能・技術伝承の危機として世間の注目を集め，特に労働集約型で且つグローバ ル化の影響を大きく受けてきた製造業はこの危機回避のために多くの時間と労力を費やした。このことは，これ

*論文 No. 13-00763 [DOI: 10.1299/transjsme.2014dsm0107]

${ }^{* 1}$ 正員, 日本海洋科学 (

*2 正員, 千葉大学大学院工学研究科（下263-8522 千葉県千葉市稲毛区弥生町 1-33）

*3 南カリフォルニア大学工学部（90089-1453 米国カリフォルニア ロサンゼルス）

E-mail: y-suzuki@yms.co.jp 
までの企業における中長期計画において，目標とする売上及び利益を達成するための生産能力，コスト，及び品 質などの計画だけでなく，それら目標に必要な人員の調達（例えば，必要な人材の技能，人数，その配置など） についても十分な計画が重要であることを示している，企業がこれら人員の調達について計画する場合，考慮す べき課題が二つある，一つ目は，必要な技能・技術を伝承するための手法という教育視点の課題である．この教 育視点の課題については，既に多くの手法及びその支援技術が研究されている．もう一つは，生産量，コスト， 品質など, その時々のマネジメントへの要求を勘案し，どの様に人員配置を変更して生産プロセスを再設計する のかというマネジメント視点の課題である. 現場マネージャーにとって, 利用可能な人材の技能レベルに応じて どの様に人員配置を変更するべきか, またその変更によってどの程度の生産能力, コスト，および品質が期待で きるのか予測することは重要である，例えば，一度に多数の人材を教育すれば，より短期間に生産能力の増強を 期待できるが，その間の生産現場における利用可能な人材の技能レベルの大幅な低下がコスト又は品質の点でリ スクとなる，その一方，少しずつ人材を教育すれば，その間のコストと品質への影響は軽微だが，技能習熟者数 の増加速度は遅く, 目標とする生産能力まで増強するのに期間を要する. どの様な, 経路をたどって人材を調達 (技能伝承) 寸るかは, その時々の企業戦略や需要動向などマネジメントへの要求で異なる. 本論文は, マネジ メントへの要求に応じて, 適切と思われる人材調達経路（技能伝承方法）を, シミュレーションによる生産プロ セスの評価結果を応用して, 評価・選択する手法により，上述の 2 つ目の課題に焦点を当てる. 本論文では，ま ず，（1）利用可能な人員の技能レベルに応じた技能伝承過程の人員配置の変更が，生産能力など生産プロセスの 性能一与える影響の予測方法について説明する. 次に, それら予測をもとに (2) 技能伝承の進め方と生産プロセ ス性能の関係について検討する方法について説明する. 最後に, その検討結果をもとに（3）技能伝承の期間, 生 産能力, 生産効率など, 生産プロセスの要求に応じて, より適切な技能伝承の進め方を選択する手法について説 明する。

\section{$1 \cdot 2$ 関連研究と課題}

技能伝承に関しては, 企業及び研究者によって様々なアプローチから提案が行われ, 大きな成果を上げている. まず，組織的な教育制度の整備及び標準化によるアプローチがある．例えば，技能師範制度（Tamai and Tsukasa， 2006）は，従来型の技能伝承である OJT（オン・ジョブ・トレーニング）とは異なり，ライン業務から作業員を はずして, 都度必要な技能伝承を行う技能伝承制度である. 次に, 熟達技能者の技能を他者に容易に伝達するこ とのできない暗黙知（Polanyi, 1962）（野中他，1996）と考え，SECI モデル（野中他，1996）の視点から，その形 式化によって技能伝承を支援する技術的アプローチがある．例えば，情報技術による知識獲得フェーズの支援技 術（稗方他，2005）（Hiekata, et al., 2007）は，設計ワークとその構成するワークフローの関係を可視化テンプレー トで形式化し, 且つセマンティック Web 技術によってそれら形式化された知識を蓄積及び再利用寸ることで, 造 船業における熟練設計者の設計技能の伝承を支援する. また, きさげ作業の遠隔技能伝承システム (福田, 丹羽,

2006）は，きさげ作業時の力と力の方向など技能に関連する動作要素を数值によって形式化し，且つそれらデー タ及び関連する情報を Web ネットワークで送信することで, 遠隔地間の技能伝承も支援する. 更に, 視覚, 聴覚, 嗅覚, 力覚など, 形式化が極めて困難な感覚と関連した知識の共同化から内面化までを, AR (拡張現実: Augmented Reality）技術による仮想空間で支援する技術的アプローチがある．例えば，没入型 VR システムによる鋳造方案 の教育支援技術（綿貫，小島，2007）は，トレーニーが AR 技術による仮想空間でのインターアクティブな体験 を通して, 鋳造方案の立案において必要な知識を, 視覚情報と力覚情報を組み合わせた場の知識として体得する ことを支援する.

しかし，これら研究は，技能伝承又は技能伝承行為そのものを支援する教育視点のものがほとんどで，所定の 技能伝承を完了するまでに，どの様に生産プロセスを再設計するのかという現場マネジメント視点のものではな い. また，それらプロセスの再設計が，生産プロセス性能に与える影響についての検討を行ったものもない，そ の様な状況において現場マネージャーは, 生産能力, 品質, コストなど, 生産プロセスの要求性能と, 手持ちの 作業員の技能習熟段階に応じて人員配置を変更し, 且つ目標の技能要求を満足するための技能伝承を計画 - 管理 している. そこで本研究では, 生産プロセスの再設計が生産プロセス性能一与える影響を検討し, 且つ適切な技 能伝承の進め方を選択するためのシミュレーションによる定量的な分析手法を提案する. 


\section{2. シミュレーションによる生産プロセスの定量的分析手法}

離散型シミュレーション（Discrete Event Driven Simulation）は，事象（Event）を離散的に発生させて，これを 待ち行列（Queue）で一定時間保持した後に開放する動作によって，ビジネスにおける仕事の発生とその処理を 模擬することができる一般的によく知られたシミュレーション方法である. しかし，生産プロセスの性能につい て検討を行うためには，上述の技術に加えて次の要件を満足する必要がある．まず，様々に異なるプロセスにつ いても，同じ定義に基づいて記述し且つ動作する，生産プロセス全般に共通な基本構造モデル及び基本動作モデ ルが必要である. 次に，それら基本モデルは，人員配置，人員の技能特性，プロセス構造，作業特性，コミュニ ケーションライン, 組織特性, 需要特性, 及び処理する仕事など, 生産プロセスを構成する要素を含み, 且つそ れら要素間のインターアクションによって，そのプロセスのメカニズムを模擬できる必要がある.

そこで, 本研究では, 上述の課題を鑑みて, PMT (Process Management Tool）（鈴木他, 2008）(Yahyaei, et al., 2009) （鈴木他，2009）（Suzuki, et al., 2010）（Suzuki, et al., 2012）というシミュレーションシステムを利用した. PMT の 基本構造モデル（図 1）は, 生産プロセスなど企業の業務プロセスは, 顧客などクライアントからの要求を処理 するシステムであると定義し，様々なクライアントの要求（COP：クライアント・オペレーション）に応じて業 務プロセスをそれぞれ関連付けることができる. COP は, クライアントの要求の発生源で, 発生頻度などその特 性に従って要求を発生し, これを対応する業務プロセスへ送信する. 業務プロセスは, 組織モデル, プロセスモ デル，リソースの集合として定義される．組織モデルにおいて，組織はチーム及び役職など組織の構成メンバー

（ポジション）とその間の報告・指示関係のネットワーク構造で定義される. プロセスモデルは顧客からの要求 を処理するのに必要な作業（SOP：サービス・オペレーション）とそれら作業間の関係によって定義される．組 織モデルの構成メンバーであるポジションと，リソースモデルのリソースは，業務プロセスを実行するための資 源として定義される．PMT の基本動作モデルは，組織を情報処理システムとして捉え（Weber, 1997）（March and Simon, 1993）（Galbraith, 1997）よってポジションは, 顧客からの要求の処理に際しては, 作業に際して生じる例外 についての意思決定, 及び作業に必要な情報提供などの情報処理作業も行う。これら例外及び情報提供要求は, 実行する作業の難易度とこれを害行するポジションの技能レベルの一致性，及び作業間の情報依存性（Lawrence and Lorsch, 1967）（Galbraith, 1997）（Thompson, 1967）に応じて，それぞれ確率的に発生する。これら明確な構造定 義と動作定義によって, PMT は, 業務プロセスの構造とその構成要素の特性が, 処理時間や処理能力など業務プ ロセスの性能に与える影響を，不確実性を加味して検討（Baligh and Damon, 1980）（Baligh and Burton, 1982）（Malone, 1987）することを可能としている.

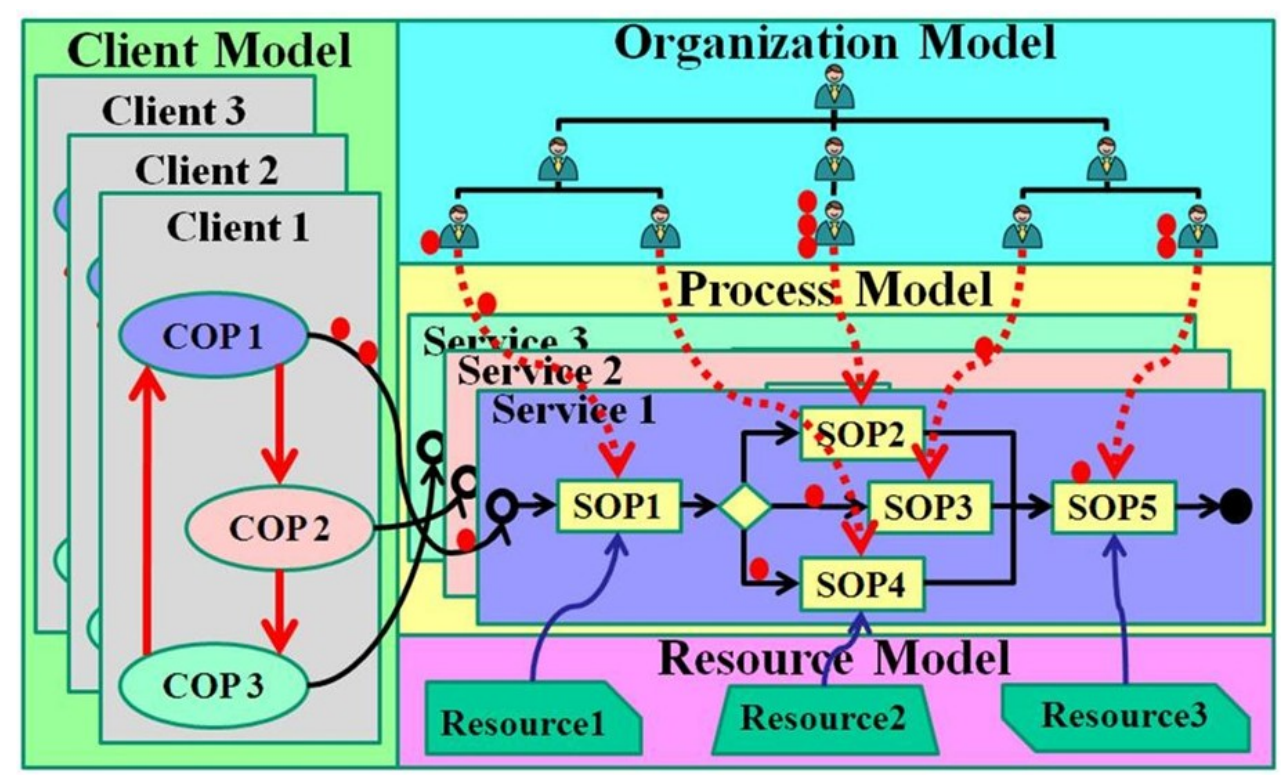

Fig.1 A conceptual structure model of PMT composed of clients, processes, an organization and resources 


\section{3. 生産能力のシミュレーション予測}

本章では，技能伝承における人員配置，及びその人員の技能レベルが，生産能力など生産プロセスの性能へ与 える影響を予測する，そこでまず，本研究事例を広範な生産プロセスにおいても適応できるよう，単純で且つ一 般化された生産プロセスを用意した，本生産プロセスは，実際のアルミダイカスト製造プロセスを参考に，(1)加 工環境分析, (2) 1 次加工機操作, (3) 1 次加工機調整, (4) 2 次加工機操作, (5) 1 次製品検査, の 5 工程に分割した. 参考にした製造プロセスの場合，1次加工機は鋳造機に，2 次加工機は裁断機にそれぞれ相当する. (1)加工環境分 析は，1 次加工機を操作する前に，その操作設定に関する情報， 1 次製品検査情報，気温，湯温，製品形状などか ら，例えば参考とした鋳造機操作の場合，材料温度，投入速度，鋳造機調整の判断など， 1 次加工機操作に関寸 る分析を行う作業工程である. (2)1 次加工機操作は, (1)の分析結果に従って, 1 次加工機を操作する作業工程であ り，例えば実際に鋳造機を設定・操作するような作業である. (5) 1 次製品検查は, 1 次加工機によって製造された 半製品の品質を見極める作業工程で，例えば鋳造機によって加工された鋳造品の巣，欠け込み，焼きつきなど， 鋳造工程における不良を確認する作業である. (4)2 次加工機操作は, (5)で合格した半製品を 2 次加工する作業工 程で，例えば検査に合格した鋳造品を裁断機によって加工する様な作業である. (3)1 次加工機調整は, (5)おけ る 1 次製品検査情報及びその他製造環境に鑑みて，必要があると判断した場合は，1 次加工機を停止し，例えば 鋳造機の場合，金型洗浄，交換，射出速度・量変更など，必要な調整を 1 次加工機に対して行う作業である. (1) 〜(5)までの全ての技能を習熟した作業員は，通常(1)〜(5)までの全ての工程を 1 人で行う．また，工程ごとに人員 を配置する場合は，1 次加工機操作に関する工程(1)(2)(3)と 2 次加工機操作に関する工程(4)(5)にそれぞれ 1 人ずつ 配置する.

\section{3-1 作業員の技能特性と可能な人員配置}

表 1 には，作業員が対象とする生産プロセスの作業(1)〜(5)において必要な技能の習熟段階を 3 つに区分し，各 段階において習熟している技能の種類，技能レベル，及び必要な期間をまとめた． 1 次加工機操作に関する技能 (1)(2)(3)を習得するためには，まず，2 次加工機操作に関する技能(4)(5)を習熟する必要がある. これら技能を習得 するのに要する期間は，(4)(5) 1 年未満，(1)(2)(3)は， 2 年未満と仮定した. L0 段階では，トレーニーは 2 次加工 機に関する作業(4)(5)の技能を習得するため専ら 2 次加工機に配置され，トレーナーは 1 次加工機に配置される. L2 段階では，トレーニーは生産ライン全ての作業について技能の習熟を完了し，トレーナーと同等となっている ので，1つの生産ライン全ての作業に配置される．L1 段階においては， 2 次加工機に関する作業(4)(5)の習熟を完 了したトレーニーは，1 次加工機に関する作業(1)(2)(3)ついて技能習得を行う．そこでトレーナーの指導と監督 の元, 既に習熟した 2 次加工機についての作業に加えて 1 次加工機についての作業も行い, 徐々に 1 つの生産 イン全ての作業を 1 人で行うようになる．表 1 には，トレーニー及びトレーナーそれぞれの配置を，トレーニー の技能レベルごとに示している.

Table 1 Description of skill development states by total experience, skill levels and human resource allocation

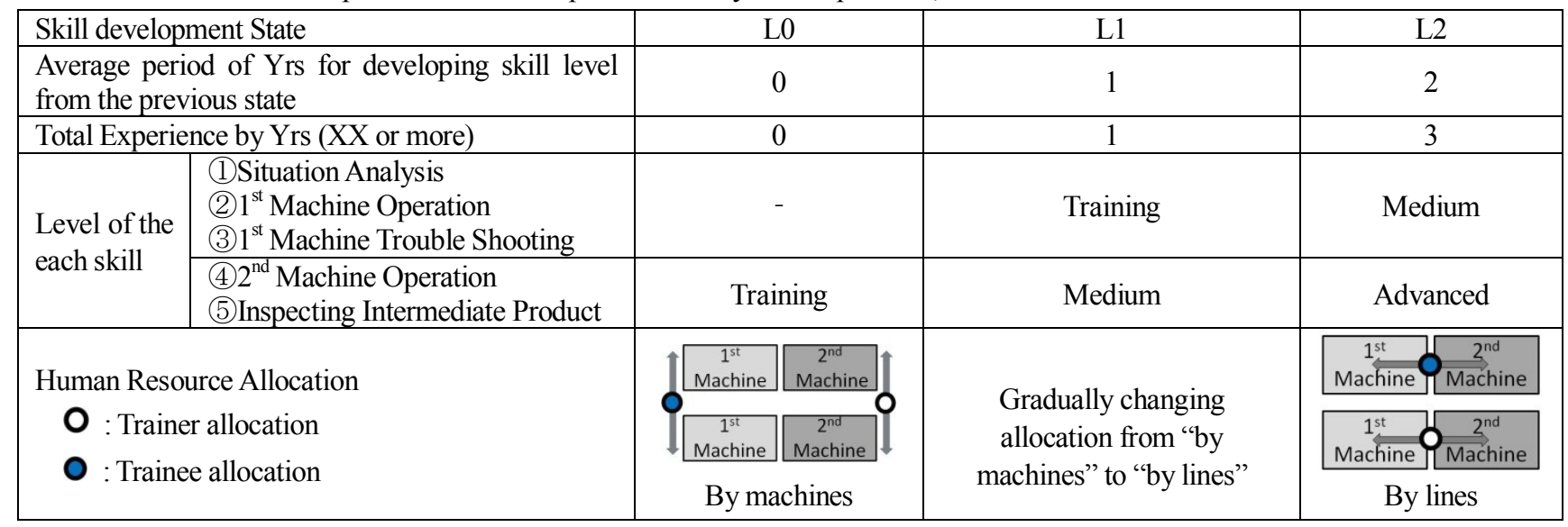


（1） L0 段階： 1 次加工機操作に関する技能を習得するための条件である 2 次加工機操作について，その技 能を習得する.

（2）L1 段階： 技能(4)(5)習熟後，1 次加工機操作に関する技能(1)～(3)を習得する.

（3）L2 段階：（1)（5)までの技能全てを習熟し全工程を1人で行える. トレーナーとして指導できる.

\section{$3 \cdot 2$ 各習熟段階における生産量予測}

全ての技能を習熟した作業員は，1 人で 1 つの生産ラインを操作することとなる．そこで本研究では，トレー ナーとトレーニー2 人の作業員は, 全ての技能習熟段階を通して, 2 つ生産ラインを操作しながら技能伝達を 行うものと仮定する. 生産量の予測については, L0 段階では簡単のため生産量はほぼ 0 であると仮定し， 2 次加 工機操作に関連する技能を習熟した段階 L1 と， 1 次加工機操作に関する技能を含めたライン全ての技能を習熟し た段階L2について, シミュレーションを実行した.

\section{$3 \cdot 2 \cdot 1 \quad$ シミュレーションモデル}

図 2 は，2つの生産ラインで製造する製品と，製造プロセスの関係をモデルしたものである. 製品 1,2 は製造 すべき製品を表し，これら製品についての注文を受けて製造プロセスがそれら注文を処理するという関係を記述 している.

図 3 は，製品 1 及び 2 の製造に際して，製造プロセスに対して要求される処理要件である．1つは，注文を処 理し所定の製品を製造するという要件で “製造注文”で示されている．もう1つは，製品の製造において確率的 に発生するトラブルに対応するという要件で“トラブル対応”で示されている.

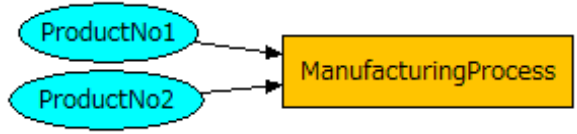

Fig.2 Simulation model describing the relations between products and manufacturing process

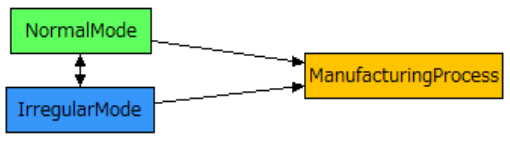

Fig.3 Simulation model describing the relations between order modes and manufacturing process

図 4 及び図 5 は，2 種類の製品（製品 1 及び 2）について発生する要件（製造注文とトラブル対応）を処理する “製造プロセス”の具体的処理プロセスを表している．製品 1 に関する注文は図中の上側の作業フローで，製品 2 に関する注文は下側の作業フローにて処理される. 製品 1 及び 2 とも製品の製造工程は全く同じで, 1 つの注文 につき, 製造環境分析, 1 次加工機操作, 1 次製品検查, 2 次加工機操作又は 1 次加工機調整の順で作業が実行さ れる. 1 次製品検査においては, 1 次加工機調整の必要性の有無が判断され，必要ありと判断された場合には，2 次加工機操作より優先して 1 次加工機の調整が行われる. 各作業の優先度は異なり, 1 次加工機調整は他の作業 に優先して先に実行される. 各作業の優先順位については, その他の作業特性とともに，表 2 に示寸とおりであ る.

Table 2 Characteristics of operations composing the manufacturing process

\begin{tabular}{|c|c|c|c|c|c|}
\hline Operation Name & $\begin{array}{l}\text { (1) Situation } \\
\text { Analysis }\end{array}$ & $\begin{array}{l}\text { (2) } 1^{\text {st }} \text { Machine } \\
\text { Operation }\end{array}$ & $\begin{array}{l}\text { (3) Inspecting } \\
\text { Intermediate } \\
\text { Product }\end{array}$ & $\begin{array}{l}\text { (4) } 2^{\text {nd }} \text { Machine } \\
\text { Operation }\end{array}$ & $\begin{array}{l}\text { (5) } 1^{\text {st }} \text { Machine } \\
\text { Trouble } \\
\text { Shooting }\end{array}$ \\
\hline Priority & $3 \mathrm{rd}$ & $3 \mathrm{rd}$ & 2nd & $3 \mathrm{rd}$ & $1 \mathrm{st}$ \\
\hline Work Volume man-hrs & 0.000 & 2.000 & 0.666 & 1.333 & 5.000 \\
\hline $\begin{array}{l}\text { Complexity by effect on operation } \\
\text { processing speed }\end{array}$ & 1.0 & 1.0 & 1.0 & 1.0 & 1.0 \\
\hline $\begin{array}{l}\text { Information dependency by times of } \\
\text { communication requests per an } \\
\text { operation execution }\end{array}$ & $\begin{array}{c}1 / 1 \\
\text { (High) }\end{array}$ & 0 & $\begin{array}{l}1 / 10 \\
(\mathrm{Low})\end{array}$ & 0 & 0 \\
\hline
\end{tabular}


作業工数（人分）は，標準的な技能水準の作業者が 1 人で作業を行った際の作業処理時間に相当する. 作業難 易度は，作業に必要なステップ及び技能の複雑さを定量化した尺度で，作業担当者の技能レベルとともに，作業 処理時間の伸縮へ影響を与える. 本事例検証では簡単のため, 作業難易度の違いが処理速度へ与える影響を全作 業同程度（1.0）と仮定した．情報依存度は，他の作業からの情報が必要な作業について，どの程度の頻繁で情報 開示を要求するかを示し，情報依存度が高いほどより多くのコミュニケーションを行おうとする.

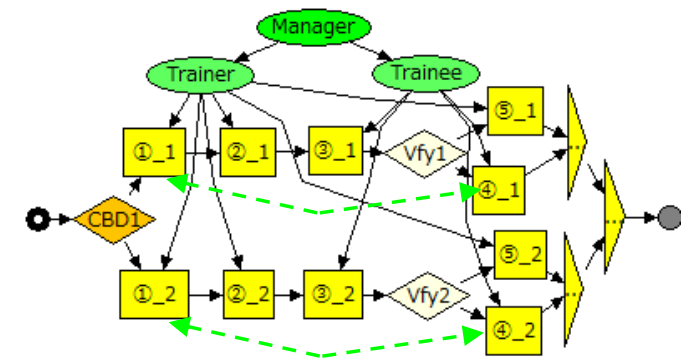

Fig.4 A simulation model of the manufacturing process of L1 State

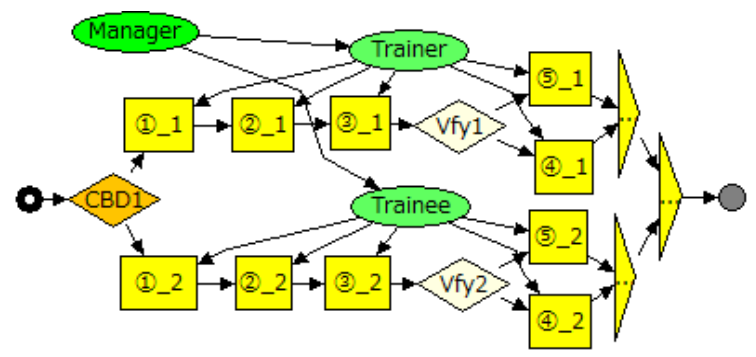

Fig.5 A simulation model of the manufacturing process of L2 State

図 4 は，トレーニーの技能習熟状況が L1 段階に到達したときの人員配置状況のシミュレーションモデルであ る. 1 次加工機操作に関する作業（製造環境分析， 1 次加工機操作， 1 次加工機調整）をトレーナーが， 2 次加工 機操作に関する作業（1 次製品検査， 2 次加工機操作）をトレーニーが行う.トレーナーが担当する製造環境の分 析には, トレーニーが担当する 1 次製品検査の情報が必要であるため, これら 2 つ作業は情報依存関係にあり， 製造環境分析と 1 次製品検査を結ぶ双方向の矢印によってこの関係を記述している. シミュレーション実行の際 には, トレーナーからトレーニーに対して，1 次製品検查情報の開示要求が送られて，この要求をトレーニーが 処理する動作を行う.これは, 必要な情報を作業者間で伝達する, いわゆるコミュニケーションを模擬している.

図 5 は, トレーニーの技能習熟状況が L2 段階に到達したときの人員配置状況のシミュレーションモデルであ る. L2 段階では, 1 次加工機操作に関する作業（製造環境分析, 1 次加工機操作, 1 次加工機調整）及び, 2 次加 工機操作に関する作業（1 次製品検查， 2 次加工機操作）を 1 人の作業員で行う。この際に，情報依存関係にある 製造環境分析と 1 次製品検査は同じ作業員で行われるため, 1 次製品検査情報の伝達の必要はない. よって, L1 段階と異なり，これら 2 つ作業は情報依存関係にはなく，コミュニケーションは行われない.

表 3 は, シミュレーションモデルにおける，L1，L2 の各習熟段階における作業員の技能レベルを示したもので ある. トレーナー作業員の技能レベルは，L1 段階，L2 段階のいずれも L2 段階の技能レベルである. トレーニー 作業員の技能レベルは，L1 段階の人員配置モデルにおいては L1 段階の技能レベルで， L2 段階の人員配置モデル においては L2 段階の技能レベルで設定されている．式（1）には，シミュレーションにおける各作業の処理時間 （処理速度）の算出における，作業工数，作業難易度，及び作業員のスキルレベルの関係を示している.

Table 3 Skill levels of staffs in each training state and the skill effect on the operational processing speed

\begin{tabular}{|c|c|c|c|c|c|}
\hline $\begin{array}{c}\text { Skill } \\
\text { development } \\
\text { State }\end{array}$ & $\begin{array}{c}\text { Situation } \\
\text { Analysis }\end{array}$ & $1^{\text {st }}$ Machine Operation & $\begin{array}{c}\text { Inspecting } \\
\text { Intermediate Product }\end{array}$ & $\begin{array}{c}2^{\text {nd }} \text { Machine } \\
\text { Operation }\end{array}$ & $\begin{array}{c}1^{\text {st }} \text { Machine Trouble } \\
\text { Shooting }\end{array}$ \\
\hline L1 & - & - & 1.0 & 1.0 & - \\
\hline L2 & 1.0 & 1.0 & 1.2 & 1.2 & 1.0 \\
\hline
\end{tabular}

$$
P S(h r)=\frac{W V(\text { man }-h r s) \times E f f_{-} c o m p}{E f f_{-} s k}
$$

PS: Processing Speed 各作業の処理に要する処理時間（時間）

$W V$ : Work Volume 各作業の平均的な作業量（人時間） 


\section{Eff_comp: Complexity Effect 各作業の難易度が処理速度へ与える影響の係数 Eff_sk: Skill Effect＼cjkstart各作業に対する技能レベルが処理速度へ与える影響の係数}

\section{$3 \cdot 2 \cdot 2$ シミュレーション}

$\mathrm{L} 1$ 及び $\mathrm{L} 2$ 習熟段階の人員配置モデルに対して，製造注文の発生数が異なる 7 つのナリオを用意し，それら シナリオにおけるシミュレーション結果から生産能力を推定した. 生産能力の推定には, 各シナリオにおけるス ループット（処理数量）に関するシミュレーション結果を利用した。 スループットは，シミュレーション期間を 通して，対象の処理プロセスが処理することができた発生注文数である。シミュレーション期間中に発生する製 品加工オーダーとトラブル発生数は, シミュレーション設定として, 表 4 に示寸通り仮定した. これらの数字の 設定については，生産プロセスそれぞれにおいて様々であり，これら数字についての議論は本論文にとってのテ 一マの中心ではない．また，トラブルについては，その発生のバラツキの違いがその対応時間へ影響することを 防ぐ目的で，製品加工オーダー同様に一定間隔に発生すると仮定している。

Table 4 The number of generated orders and troubles in respect to the each simulation scenario

\begin{tabular}{|c|c|c|c|c|c|c|c|c|}
\hline Scenario No. & 1 & 2 & 3 & 4 & 5 & 6 & 7 \\
\hline Duration (Hrs) & \multicolumn{7}{|c|}{168} & \multicolumn{4}{|c|}{} \\
\hline No. of Orders & 3,308 & 3,780 & 4,253 & 4,725 & 5,198 & 5,670 & 6,143 \\
\hline No. of Troubles & 220 & 252 & 284 & 315 & 347 & 378 & 410 \\
\hline
\end{tabular}

\section{$3 \cdot 2 \cdot 3$ シミュレーション結果}

図 6 は，L1 段階及び L2 段階の人員配置のシミュレーション結果として, 注文発生数（受注量）増加に伴う処 理件数（スループット）の変化をプロットしたものである. トレーニーの技能習熟状況が L1 段階にある時，生 産プロセスの処理件数は, 注文発生数の増加に伴い 4,000 件程度までは直線的に増加し, それ以上に注文発生数 が増加すると 4, 100 件程度のほぼ一定となっていることが分かる.このことから，L1 段階における人員配置方法 では, 生産プロセスの処理能力の上限は, 4,100 件程度であると推測される. その一方，トレーニーの技能習熟状 況が L2 段階にある時, 生産プロセスの処理件数は, 注文発生数の増加に伴い 4,700 件程度までは直線的に増加し, それ以上に注文発生数が増加するとその増加とは逆に減少していくことが分かる.

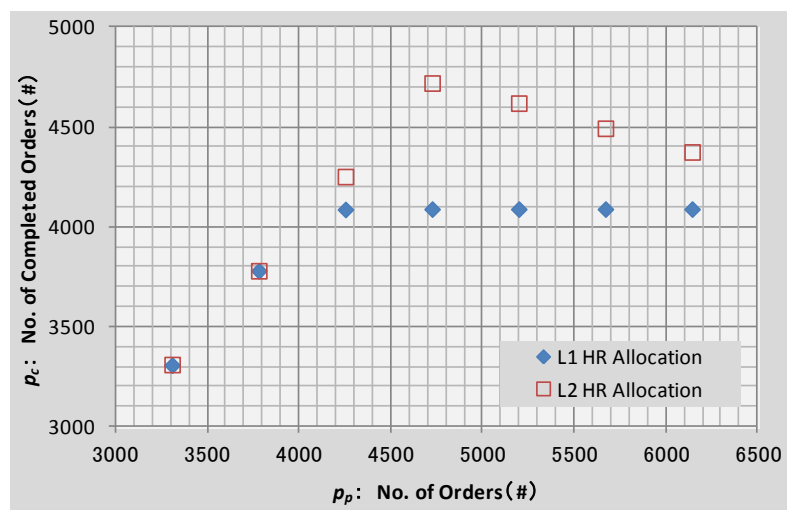

Fig.6 Number of generated and completed orders. L1, 2 are the predicted throughput by orders marked by rhombus and square respectively.

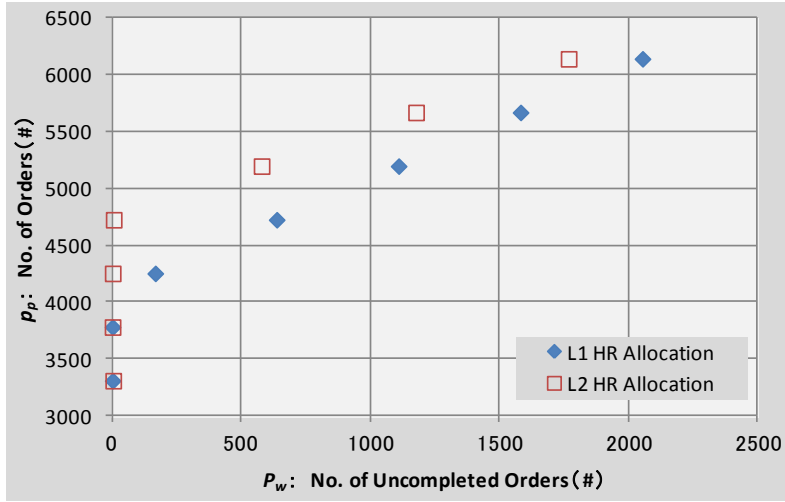

Fig.7 Number of generated and uncompleted orders. L1, 2 are the predicted throughput by uncompleted orders marked by rhombus and square respectively.

図 7 は, L1 及び L2 段階それぞれの処理残件数と処理件数 (スループット) の変化をプロットしたものである. この時, 処理残件数は, 次式で算出した. 
$P_{w}=P_{p}-P_{c}$

$P_{w}:$ 処理残件数 (件)

$P_{p}:$ 注文発生件数 (件)

$P_{c}:$ 処理件数 (件)

図 7 から，トレーニーが L1 段階又は L2 段階のいずれの技能習熟段階においても, 注文発生数がそれら人員配 置における生産プロセスの処理能力の上限を超えると, 注文発生数の増加に比例して処理残件数が増加している ことが分かる．このことから，それぞれの人員配置における生産能力の上限は，処理残件数が 0 となる最大の注 文発生件数と等価であることから，L1 段階及び L2 段階の人員配置における生産プロセス 2 ラインの最大処理能 力は次の様に予測された.

（1）L1 段階（2ライン処理能力）：4088/week

（2）L2 段階（2ライン処理能力）：4038/week

\section{4. 技能伝承に伴う生産プロセスの変遷経路}

\section{1 人員配置状況}

本事例では， 1 人の習熟した作業員を，5 人体制にするまでの技能伝承の進め方について検討する，そこで， 1 人 5 人の作業員を，その技能習熟段階を考慮して，可能な人員配置状況を表 5 にまとめた. ここでは，前項の シミュレーション結果に基づいて算出された，トレーニーの技能レベルが L1 及び $\mathrm{L} 2$ 段階の人員配置における生 産プロセスの処理能力に基づいて，それら人員配置状況における処理能力も算出した.

Table 5 Human resource allocation in respect to their availability: the enclosed number is the maximum trainees considering the allocation of 5 staffs

\begin{tabular}{|c|c|c|c|c|c|c|}
\hline \multirow[t]{2}{*}{ State } & \multicolumn{3}{|c|}{$\begin{array}{c}\text { Availability by skill development } \\
\text { state } \\
\text { (No. of staffs) } \\
\end{array}$} & \multirow{2}{*}{$\begin{array}{l}\text { No. of } \\
\text { maximum } \\
\text { trainees }\end{array}$} & \multirow[t]{2}{*}{ Maximum throughput } & \multirow[t]{2}{*}{$\begin{array}{l}\text { Human resource allocation in respect to } \\
\text { each manufacturing line }\end{array}$} \\
\hline & L2 & L1 & Total & & & \\
\hline S1 & 1 & 0 & 1 & 1 & 2,369 & $1^{\text {st }} 2^{\text {nd }}$ \\
\hline S2 & 1 & 1 & 2 & 0 & 4,088 & \begin{tabular}{|l|l|}
$1^{\text {st }}$ & $2^{\text {nd }}$ \\
$1^{\text {st }}$ & $2^{\text {nd }}$ \\
\end{tabular} \\
\hline S3 & 2 & 0 & 2 & 2 & 4,738 & 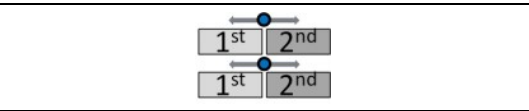 \\
\hline S4 & 2 & 1 & 3 & 1 & 6,457 & 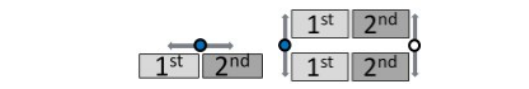 \\
\hline S5 & 3 & 0 & 3 & $\begin{array}{c}3 \\
(2)\end{array}$ & 7,107 & 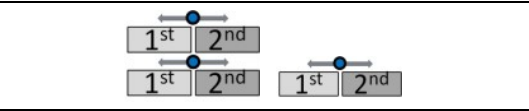 \\
\hline S6 & 2 & 2 & 4 & 0 & 8,176 & 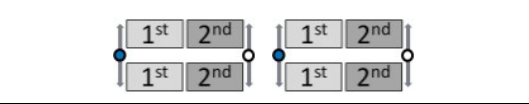 \\
\hline S7 & 3 & 1 & 4 & $\begin{array}{c}2 \\
(1)\end{array}$ & 8,826 & 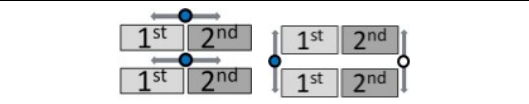 \\
\hline S8 & 4 & 0 & 4 & $\begin{array}{c}4 \\
(1)\end{array}$ & 9,476 & 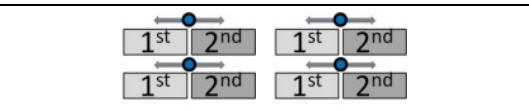 \\
\hline
\end{tabular}




\begin{tabular}{|c|c|c|c|c|c|c|}
\hline S9 & 3 & 2 & 5 & $\begin{array}{c}1 \\
(0)\end{array}$ & 10,545 & 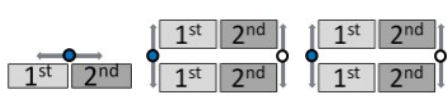 \\
\hline S10 & 4 & 1 & 5 & $\begin{array}{c}3 \\
(0)\end{array}$ & 11,195 & 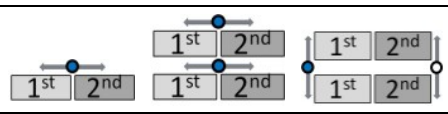 \\
\hline S11 & 5 & 0 & 5 & $\begin{array}{c}5 \\
(0)\end{array}$ & 11,845 & 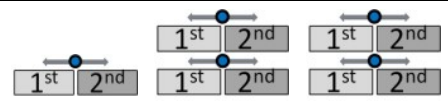 \\
\hline
\end{tabular}

（1）人員配置状況 S1： S1 は， L2 段階の技能習熟作業者が，1人のみの人員配置である. 技能伝承は，この 状況を始点とし，L0 段階の技能習熟作業者をトレーニーとして教育することから開始されるものとする.

（2）人員配置状況 S2： S2 は，L2 段階の技能習熟作業者 1 人と L1 段階の技能習熟作業者が， 2 つの生産ラ インにおいて，それぞれ 1 次加工機操作と 2 次加工機操作に関する作業を行う人員配置である. トレー ニーは L0 から L1 段階への技能習熟を完了し，これから L2 段階へ技能習熟を向上させる.

（3）人員配置状況 S3：S3 は，L2 段階の技能習熟作業者 2 人が，それぞれ 1 つの生産ラインに配置され，そ の全工程に関する作業を 1 人で行う人員配置である．L1 段階の技能習熟作業者が，追加のトレーニング でその技能習熟を L2 段階へ向上させることで可能となる．この状況では，最大で 2 人のトレーニーに対 して新たに技能指導を行うことが可能である.

（4）人員配置状況 S4： まず， L2 段階の技能習熟作業者 2 人のうち 1 人がトレーナーとして新たなトレーニ -1 人と 2 つ生産ラインにおいて, それぞれ 1 次加工機操作と 2 次加工機操作に関する作業を行う.ま た，技能習熟作業者のもう 1 人は 1 つの生産ラインの全工程の作業を行う人員配置である. この状況で は，最大で 1 人のトレーニーに対して，新たに技能指導を行うことが可能である.

（5）人員配置状況 S5： L2 段階の技能習熟作業者 3 人が，それぞれ 1 つの生産ラインに配置され，その全工 程に関する作業を 1 人で行う。この状況では, 最大で 3 人のトレーニーに対して, 新たに技能指導を行 うことが可能である. ただし，本ケースでは， 5 人の作業者の技能を開発することを目的としたので，最 大で 2 人のトレーニーということとなる.

（6）人員配置状況 S6： L2 段階の技能習熟作業者 2 人と新たなトレーニー2 人が， 2 つのチームを組み，そ れぞれ 2 つ生産ラインの作業を行う。この時, トレーナーは 1 次加工機操作, トレーニーは 2 次加工 機操作に関する作業を行う.

（7）人員配置状況 S7： L2 段階の技能習熟作業者 3 人のうち 1 人が，トレーナーとして新たなトレーニー1 人と $2 つ の$ 生産ラインにおいて, それぞれ 1 次加工機操作と 2 次加工機操作に関する作業を行う. また, 技能習熟作業者の残り 2 人は，それぞれ 1 つの生産ラインの全工程の作業を行う人員配置である.この 状況では，最大で 2 人のトレーニーに対して，新たに技能指導を行うことが可能である.

（8）人員配置状況 S8： L2 段階の技能習熟作業者 4 人が，それぞれ 1 つの生産ラインに配置され，その全工 程に関する作業を 1 人で行う。この状況では, 最大で 4 人のトレーニーに対して, 新たに技能指導を行 うことが可能である．ただし，本ケースでは， 5 人の作業者の技能を開発することを目的としたので，最 大で 2 人のトレーニーということとなる.

（9）人員配置状況 S9： L2 段階の技能習熟作業者 3 人のうち 2 人と新たなトレーニー 2 人が， 2 つのチーム を組み, それぞれ 2 つ生産ラインの作業を行う。この時, トレーナーは 1 次加工機操作, トレーニー は 2 次加工機操作に関する作業を行う．また，残りの技能習熟作業者 1 人は，1つの生産ラインの全工程 の作業を行う人員配置である. この状況では, 最大で 1 人のトレーニーに対して, 新たに技能指導を行 うことが可能である. ただし，本ケースでは， 5 人の作業者の技能を開発することを目的としたので，こ れ以上のトレーニーは求めないものとする.

（10）人員配置状況 S10： L2 段階の技能習熟作業者 4 人のうち 1 人と新たなトレーニー 1 人が， 1 つのチー ムを組み, 2 つ生産ラインの作業を行う。この時, トレーナーは 1 次加工機操作, トレーニーは 2 次加 工機操作に関する作業を行う。 また, 残りの技能習熟作業者 3 人は, 1 つの生産ラインの全工程の作業を 行う人員配置である. この状況では, 最大で 3 人のトレーニーに対して，新たに技能指導を行うことが 
可能である.ただし，本ケースでは，5人の作業者の技能を開発することを目的としたので，これ以上の トレーニーは求めないものとする.

（11）人員配置状況 S11：Ｌ2 段階の技能習熟作業者 5 人が，それぞれ 1 つの生産ラインに配置され，その全 工程に関する作業を 1 人で行う。この状況では, 最大で 5 人のトレーニーに対して, 新たに技能指導を 行うことが可能である. ただし, 本ケースでは， 5 人の作業者の技能を開発することを目的としたので, これ以上のトレーニーは求めないものとする.

\section{$4 \cdot 2$ 技能伝承の進め方}

図 8 には, 表 5 に基づいて, 熟達した作業員 1 人から, どの様な人員配置状況を得て, 最終的に 5 人の熟達し た作業員を得ることができるのか，その可能な技能伝承の進め方を示している．今回の対象ケースでは，Path_A から Path_Eまでの 5 つの技能伝承の進め方が考えられる. 全ての技能伝承の進め方において，1 人の技能習熟作 業者 (L2 段階) が 2 人目の技能習熟作業者を育成するまでに通る S1 から S3 までの技能伝承の進め方は共通であ る. S3，S4，S5，及び S7 においては，トレーニーの人数が 1 人又は 2 人であるかによって，その経路が分岐す る. Path_Aは，12 年をかけて最もゆっくりと技能伝承を行う経路で，常に 1 人だけトレーニーを指導する. その 一方 Path_C 及びPath_E は，一度に 2 人のトレーニーを指導する 9 年の最短の経路である.

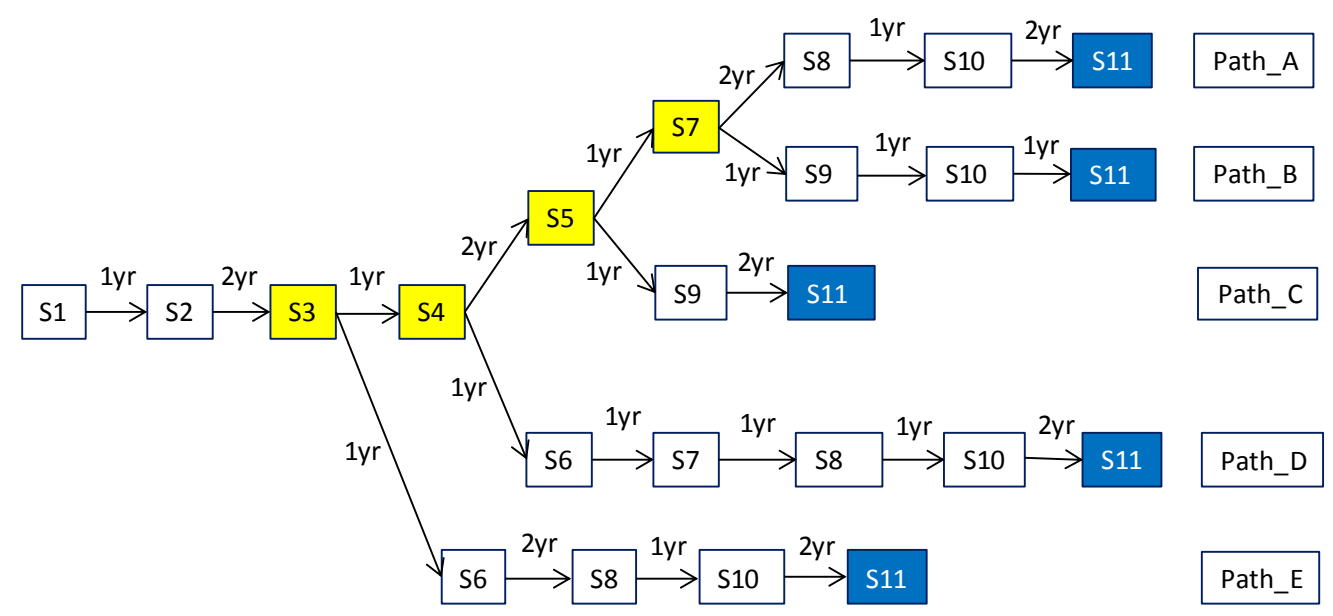

Fig.8 Possible paths of human allocation changes for achieving 5 skilled staffs team from a staff

\section{5. 最適な技能伝承の進め方についての検討}

\section{$5 \cdot 1$ 評価方法}

本事例において目標とする 5 人の技能習熟作業者を育成するための技能伝承の進め方は，前章において述べた ように, Path_Aから Path_Eまでの 5 経路が想定された。 そこでこれら経路について，事例提供元の現場要望に 基づいて, “生産能力の維持のし易さ”, “技能習熟の促進のし易さ”の 2 つの視点から評価を行った. これら評価 においては，処理能力，延平均処理コスト，及び延期間の 3 つの指標を利用した.

（1）処理能力（件 / 時間）： 表 5 にて算出したシミュレーション期間（7 日間 $\times 24$ 時間 $=168$ 時間）におけ る処理能力に対応しており，これを 1 時間当たりの処理能力に換算している.

（2）延期間（年）：技能伝承の進め方において通過する人員配置に対応した処理能力を達成するまでに要し た期間で，図 8 にて示す各人員配置間の期間を経路に沿って合算している.

（3）延平均処理コスト（人時間／件）：技能伝承の開始から S2～S11 など特定の処理能力を達成するまでの 期間における 1 件の処理あたりの平均工数で, 次式で算出される. 
$C_{p}=\frac{\# h r}{P_{c}}$

$c_{p}$ ： 延平均処理コスト 注文 1 件を処理する際の作業工数（人時間/件）

$\# h r:$ 期間内の延作業工数（人時間）

$p_{c}$ : 期間内に処理された延注文件数（件)

\section{$5 \cdot 2$ 各技能伝承の進め方の評価検討}

表 6〜表 10 は，技能伝承過程における人員配置状況の，延期間，処理能力，及び延平均処理コス卜を，技能伝 承の進め方（Path A〜Path E）ごとに示している.

Table 6 Changes of process performances and human resource allocation along path A

\begin{tabular}{|c|c|c|c|r|r|r|}
\hline State & Period Yr & $\begin{array}{c}\text { Learning } \\
\text { duration Yrs }\end{array}$ & $\begin{array}{c}\text { Processing Speed } \\
(\mathrm{No} / \mathrm{Hr})\end{array}$ & \multicolumn{1}{c|}{$\begin{array}{c}\text { Total Throughput } \\
(1,000 \times \text { No. })\end{array}$} & $\begin{array}{c}\text { Total Work Hours } \\
(1,000 \times \text { man-hrs })\end{array}$ & \multicolumn{1}{c|}{$\begin{array}{c}\text { Average Cost } \\
\text { (No./man-hrs })\end{array}$} \\
\hline S1 & 0 & 0 & 14.1 & 0 & 0 & 17 \\
\hline S2 & 1 & 1 & 24.3 & 168 & 52 & 704.1 \\
\hline S3 & 2 & 3 & 28.2 & 628 & 131 & 83.6 \\
\hline S4 & 1 & 4 & 38.4 & 920 & 166 & 80.7 \\
\hline S5 & 2 & 6 & 42.3 & 1,627 & 236 & 81.5 \\
\hline S7 & 1 & 7 & 52.5 & 2,043 & 280 & 78.9 \\
\hline S8 & 2 & 9 & 56.4 & 2,997 & 367 & 79.3 \\
\hline S10 & 1 & 10 & 66.6 & 3,536 & 4,737 & 77.7 \\
\hline S11 & 2 & 12 & 70.5 & & & \\
\hline
\end{tabular}

Table 7 Changes of process performances and human resource allocation along path B

\begin{tabular}{|c|c|c|r|r|r|r|}
\hline State & Period Yr & $\begin{array}{c}\text { Learning } \\
\text { duration Yrs }\end{array}$ & $\begin{array}{c}\text { Processing Speed } \\
(\text { No./Hr })\end{array}$ & \multicolumn{1}{c|}{$\begin{array}{c}\text { Total Throughput } \\
(1,000 \times \text { No. })\end{array}$} & $\begin{array}{c}\text { Total Work Hours } \\
(1,000 \times \text { man-hrs })\end{array}$ & \multicolumn{1}{c|}{$\begin{array}{c}\text { Average Cost } \\
\text { (No./man-hrs })\end{array}$} \\
\hline S1 & 0 & 0 & 14.1 & 0 & 0 & 17 \\
\hline S2 & 1 & 1 & 24.3 & 168 & 52 & 704.1 \\
\hline S3 & 2 & 3 & 28.2 & 628 & 131 & 83.6 \\
\hline S4 & 1 & 4 & 38.4 & 920 & 166 & 80.7 \\
\hline S5 & 2 & 6 & 42.3 & 1,627 & 210 & 81.5 \\
\hline S7 & 1 & 7 & 52.5 & 2,043 & 254 & 82.5 \\
\hline S9 & 1 & 8 & 62.8 & 2,548 & 297 & 81.6 \\
\hline S10 & 1 & 9 & 66.6 & 3,114 & & 80.2 \\
\hline S11 & 1 & 10 & 70.5 & 3,715 & & \\
\hline
\end{tabular}

Table 8 Changes of process performances and human resource allocation along path $\mathrm{C}$

\begin{tabular}{|c|c|c|r|r|r|r|}
\hline State & Period Yr & $\begin{array}{c}\text { Learning } \\
\text { duration Yrs }\end{array}$ & $\begin{array}{c}\text { Processing Speed } \\
(\text { No./Hr })\end{array}$ & $\begin{array}{c}\text { Total Throughput } \\
(1,000 \times \text { No. })\end{array}$ & $\begin{array}{c}\text { Total Work Hours } \\
(1,000 \times \text { man-hrs })\end{array}$ & $\begin{array}{c}\text { Average Cost } \\
\text { (No./man-hrs })\end{array}$ \\
\hline S1 & 0 & 0 & 14.1 & 0 & 0 & 17 \\
\hline S2 & 1 & 1 & 24.3 & 168 & 52 & 83.1 \\
\hline S3 & 2 & 3 & 28.2 & 628 & 78 & 85.7 \\
\hline S4 & 1 & 4 & 38.4 & 920 & 131 & 80.7 \\
\hline S5 & 2 & 6 & 42.3 & 1,627 & 262 & 83.9 \\
\hline S9 & 1 & 7 & 62.8 & 2,087 & 3,255 & 262 \\
\hline S11 & 2 & 9 & 70.5 & & & \\
\hline
\end{tabular}


Table 9 Changes of process performances and human resource allocation along path D

\begin{tabular}{|c|c|c|c|c|c|c|}
\hline State & Period Yr & $\begin{array}{c}\text { Learning } \\
\text { duration Yrs }\end{array}$ & $\begin{array}{l}\text { Processing Speed } \\
(\text { No./Hr) }\end{array}$ & $\begin{array}{l}\text { Total Throughput } \\
(1,000 \times \text { No. })\end{array}$ & $\begin{array}{l}\text { Total Work Hours } \\
(1,000 \times \text { man-hrs })\end{array}$ & $\begin{array}{l}\text { Average Cost } \\
\text { (No./man-hrs) }\end{array}$ \\
\hline S1 & 0 & 0 & 14.1 & 0 & 0 & \\
\hline S2 & 1 & 1 & 24.3 & 168 & 17 & 104.1 \\
\hline S3 & 2 & 3 & 28.2 & 628 & 52 & 83.6 \\
\hline $\mathrm{S} 4$ & 1 & 4 & 38.4 & 920 & 78 & 85.7 \\
\hline S6 & 1 & 5 & 48.7 & 1,301 & 113 & 87.5 \\
\hline S7 & 1 & 6 & 52.5 & 1,745 & 148 & 85.3 \\
\hline S8 & 1 & 7 & 56.4 & 2,222 & 183 & 82.8 \\
\hline S10 & 1 & 8 & 66.6 & 2,761 & 227 & 82.5 \\
\hline $\mathrm{S} 11$ & 2 & 10 & 70.5 & 3,962 & 315 & 79.6 \\
\hline
\end{tabular}

Table 10 Changes of process performances and human resource allocation along path $\mathrm{E}$

\begin{tabular}{|c|c|c|c|c|c|c|}
\hline State & Period Yr & $\begin{array}{c}\text { Learning } \\
\text { duration Yrs }\end{array}$ & $\begin{array}{c}\text { Processing Speed } \\
(\text { No./Hr) }\end{array}$ & $\begin{array}{l}\text { Total Throughput } \\
(1,000 \times \text { No. })\end{array}$ & $\begin{array}{l}\text { Total Work Hours } \\
(1,000 \times \text { man-hrs })\end{array}$ & $\begin{array}{l}\text { Average Cost } \\
\text { (No./man-hrs) }\end{array}$ \\
\hline S1 & 0 & 0 & 14.1 & 0 & 0 & \\
\hline $\mathrm{S} 2$ & 1 & 1 & 24.3 & 168 & 17 & 104.1 \\
\hline S3 & 2 & 3 & 28.2 & 628 & 52 & 83.6 \\
\hline S6 & 1 & 4 & 48.7 & 965 & 87 & 90.8 \\
\hline S8 & 2 & 6 & 56.4 & 1,885 & 157 & 83.6 \\
\hline S10 & 1 & 7 & 66.6 & 2,424 & 201 & 83.1 \\
\hline $\mathrm{S} 11$ & 2 & 9 & 70.5 & 3,625 & 289 & 79.7 \\
\hline
\end{tabular}

\section{$5 \cdot 2 \cdot 1$ 延期間と処理能力の関係}

図 9 は，1 人の技能習熟作業者が， 5 人になるまでに要する延期間と，それに伴う処理能力の变化を，技能伝承 の進め方ごとにプロットしたものである. 図 9 から, Path_E は, 最短の 9 年で 5 人の技能習熟作業者を育成でき ると同時に，その技能伝承過程においても常に他の経路より高い処理能力を維持することができる技能伝承の進 め方であることが分かる.その一方, Path_A は, 5 人の技能習熟作業者を育成するのがもつとも遅く 12 年を要し, またその過程における処理能力も，常に他の経路より低いことが分かる．Path_Cは，Path_E と同じく9年という 最短で 5 人の技能習熟作業者を育成することができる.しかし，技能伝承過程の 4 年目から 7 年目にかけての 3 年間ほど，Path_Dより処理能力が最大で $20 \%$ ぼ低くなることから，技能伝承期間中の処理能力維持という点に おいて Path_Cには及ばず，更に技能伝承に 10 年を要する Path_Dよりも劣る. 以上の結果より，最も“生産能力 を維持し易い”技能伝承の進め方はPath_Eで，その逆はPath_A であると言える.

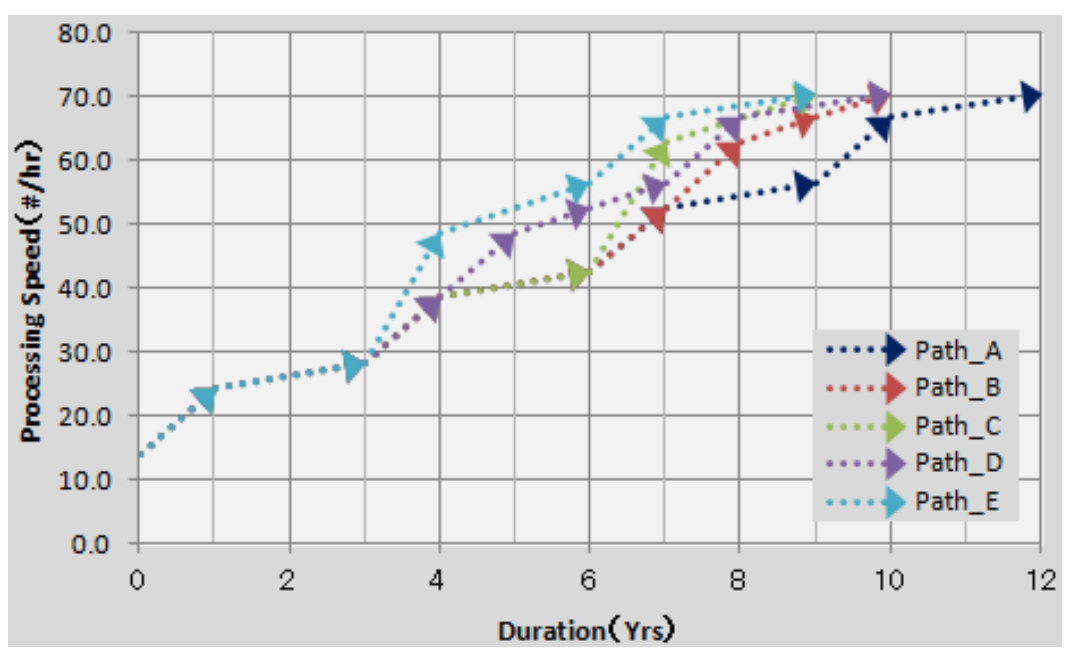

Fig.9 Changes of processing speed and training duration from S1 to S11. Path_A to E are the predicted processing speed (process capacity) by years of schedule in respect to the different procurement strategies. 


\section{$5 \cdot 2 \cdot 2$ 延期間と平均処理コストの関係}

技能伝承が促進寸れば, それに伴い処理能力も向上し，また，技能伝承期間を通しての延平均処理コストも徐々 に低下寸るはずである. 図 10 は，1 人の技能習熟作業者が， 5 人になるまでに要する延期間と，それに伴う延平 均処理コストの変化を，技能伝承の進め方ごとにプロットしたものである．図 10 から，Path_A は，技能習熟作 業者の育成に最も時間がかかるものの，その技能伝承過程においても常に他の経路より低い延平均処理コストを 維持することができる技能伝承の進め方であることが分かる．その一方，Path_E は，技能習熟作業者の育成が最 速なものの, 技能伝承開始後 3 年から 7 年目の 4 年間にかけて, 延平均処理コストが他の経路より最大で $6 \%$ 程 度高く, 高コストな技能伝承の進め方と言える. また, Path_D の延平均処理コストは，技能伝承過程の 3 年目か ら 5 年目にかけては Path_Eよりも低いものの，それ以降はPath_E とほぼ同じかそれ以上で，2 番目に高コスト な技能伝承の進め方と言える. 人事異動など, 作業員の流動的活用の視点に立つと, 延平均処理コストが高い経 路では，そのコストが高いときに人員が移動すると，人材育成のためのコストを回収することなくその果実を失 うことを意味する．よって，Path_Eの様な高コストの技能伝承の進め方は，コストの点において突然の人事異動 などによって被る影響が高いと言える. その一方，Path_Aのように，常に低い延平均処理コストを維持する技能 伝承の進め方では，その影響は小さいと言える.

以上の結果より, 最も“価格競争力を維持し易い”技能伝承の進め方は Path_A で, その逆は Path_E 又は Path_D であると言える。

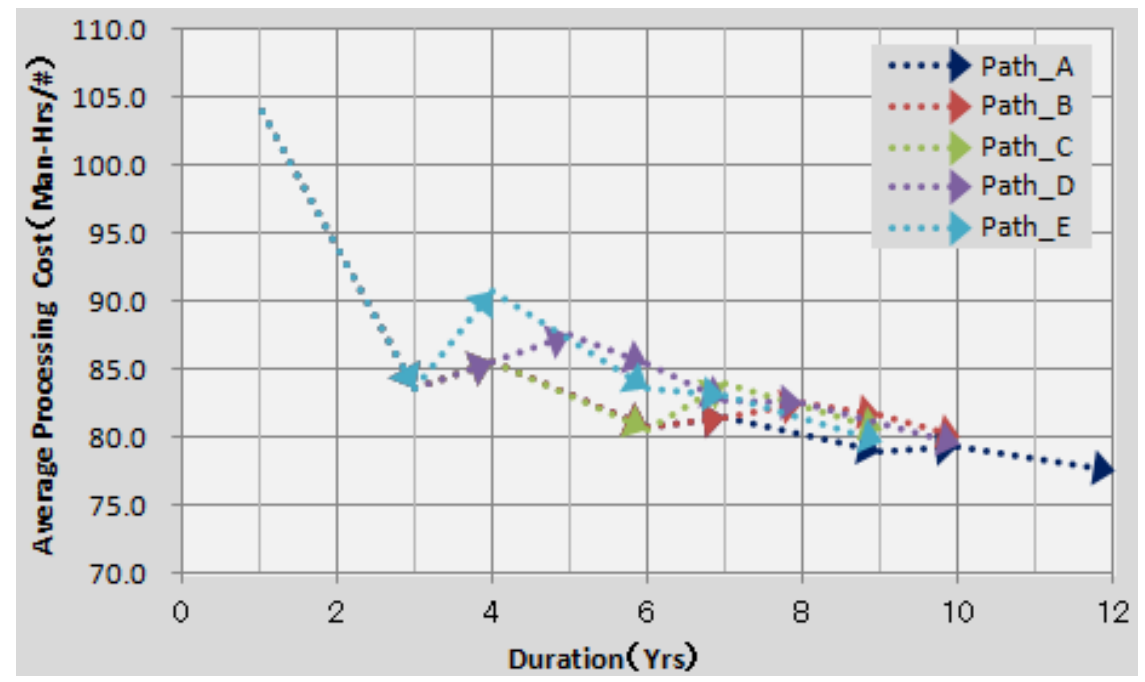

Fig.10 Changes of average cost and training duration from S1 to S11. Path_A to E are the predicted average cost by years of schedule in respect to the different procurement strategies.

\section{$5 \cdot 2 \cdot 3$ 技能伝承の進め方の選択}

本事例では，最適な技能伝承の進め方の選択を，“生産能力の維持のし易さ”，“価格競争力の維持のし易さ”, 及び “人事異動のし易さ”を評価基準として検討している．この時，生産現場を取り巻く現在と将来予測される 環境を考慮して，どの評価基準により重みを置くべきか適切なトレードオフを行うことが重要である. 例えば, 人事異動が比較的頻繁で, 且つ今後の受注増が予測されるような環境においては, 高い処理能力の維持と同時に 技能伝承期間の短さが，技能伝承の進め方の選択においてより重視される．他の例としては，需要増は期待され ないものの, 頻繁な人事異動と厳しい価格競争が予測されるような環境下では, 技能伝承期間の短さや処理能力 の高さよりも，より低く処理コストを維持できることが要求される.

そこで以下には事例として, “生産能力の維持のし易さ”, “価格競争力の維持のし易さ”, 及び “人事異動のし 易さ”について，Path_A〜Path_E ぞれぞれの技能伝承の進め方について評価を行い，更に例えば “人事異動のし 易さ”と“価格競争力の維持のし易さ”が最も重要な要件とされた場合における適切な技能伝承の進め方を特定 してみる 
図 11 は，技能伝承の進め方の評価基準，“生産能力の維持のし易さ”，“価格競争力の維持のし易さ”，“人事異 動のし易さ”について，各技能伝承の進め方を評価した結果である，人事異動のし易さについては，表 6〜表 10 の結果に基づき，技能伝承期間が最短の経路を 5 点とし，最長の経路を 1 点として評価した. 生産能力の維持の し易さについては，図 9 と $5 \cdot 2 ・ 1$ 項の考察に基づき，技能伝承期間を通して最も高い処理能力を維持した経路 を 5 点とし，その逆を 1 点とした。価格競争力の維持のし易さについては，図 10 と・2・2 項の考察に基づき， 最も低い延平均処理コストを維持した経路を 5 点とし，その逆を 1 点とした.

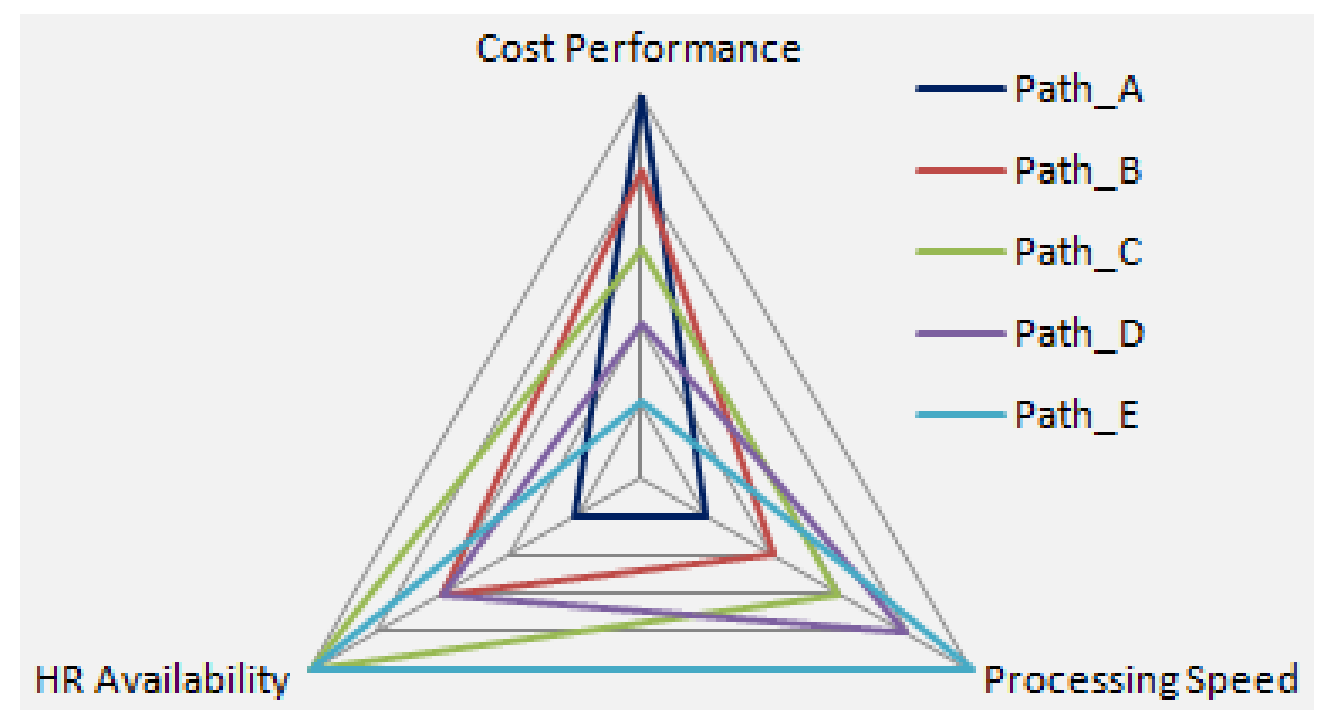

Fig.11 Evaluation of skill development paths by cost, human resource availability and processing speed. HR Availability measures how fast the strategy procures the necessary human resources. Cost performance measures human resource efficiency for the production during the procurement schedule. Processing speed measures the production capacity during the procurement schedule. Path_A to E describe the scores of the different strategies in respect to the three criterions.

図 11 より，各技能伝承の進め方の特徵として，次のことが分かった.

（1）Path_Aは，価格競争力の維持のし易さに突出した経路である.

（2）Path_Eは，人事異動のし易さと，生産能力の維持のし易さに突出した経路である.

（3）Path_A と Path_E の中間的な特徵を有し, より人事異動がし易い経路が Path_Cで, より生産能力の維持 をし易いのが Path_Dで，より価格競争力を維持し易いのが Path_Bである.

先述のとおり，本事例提供元の現場では，“人事異動のし易さ”と“価格競争力の維持のし易さ”が，最も重要 な要件とされている. この要件に照らし合わせると，Path_B 又はPath_C が，最適な技能伝承の進め方として選 択できる.

\section{6. 結 言}

一般的な製品製造プロセスを例に，需要動向，人員の流動性，競合他社との価格競争動向など，生産現場を取 り巻く環境の現状及び予測に対して最適な技能伝承の進め方を，シミュレーションを活用したアプローチで検討 した．その結果，本研究で提案するシミュレーションを活用したアプローチにより，次のことを確認できた．ま ず，トレーニーとなる作業者の技能段階に応じて変化する人員配置やその技能レベルを反映したシミュレーショ ンによって, 生産能力など生産プロセスに関する各種パフォーマンスを予測することができることを確認した. 次に, 目的の技能伝承を達成する過程において, その進渉に従って変化する生産能力など生産プロセスに関する 各種パフォーマンスを, 先のシミュレーション結果を用いて算出することができることを確認した. 最後に, 先 
に算出した生産プロセスに関するパフォーマンスから，生産能力，コスト，技能伝承期間などの評価尺度によっ て様々な技能伝承過程を評価し，生産現場の現状及び予測に対して適切な技能伝承の進め方を選択できることを 確認した.

今回の事例では, 生産プロセスは 4 工程で, 又作業者の技能習熟段階も $\mathrm{L} 0 \rightarrow \mathrm{L} 1, \mathrm{~L} 1 \rightarrow \mathrm{L} 2$ の 2 ステップと, 比 較的単純な対象について検討を行った。しかし，本研究で提案する手法は，より複雑な生産プロセス，或いは複 数の生産プロセスに対しても応用寸ることができる．本手法を生産プロセスだけでなく，施設・装置などのオぺ レーションプロセス，銀行・ホテルなどのサービスプロセスなど，様々な分野において，技能伝承及びその適切 な経路の選択支援技術としての応用が期待できる.

\section{文献}

Baligh, H. H. and Damon, W. W., Foundation for a systemic process of organization structure design, Journal of information optimization science, Vol.1, No.2 (1980), pp. 133-165.

Baligh, H. H. and Burton, R. M., Describing and designing organizational structures and processes, International journal of policy analysis information systems, Vol. 5, No. 4 (1982), pp. 251-266.

福田修一, 丹羽竜介, きさげ作業の遠隔技能伝承システムの構築, 日本機械学会論文集 C 編, Vol.72, No.716 (2006), pp.1285-1290.

Galbraith, J., Organization design (1977), Addison-Wesley, p.426.

稗方和夫, 内藤紀彦, 大和裕幸, 安藤英幸, 中澤崇, 造船業における知識伝承システムに関する研究 : 情報技術に よる知識獲得フェーズの支援, 日本船舶海洋工学会論文集, Vol. 2 (2005), pp.131-137.

Hiekata, K., Yamato, H., Oishi, W. and Nakazawa, T., Ship design workflow management by ShareFast, Journal of ship production, Vol. 23, No. 1 (2007), pp.23-29.

Lawrence, P. R. and Lorsch, J. W., Organization and environment, Harvard business press (1967), p.296.

March , J. G. and Simon, H. A., Organizations, John wiley \& sons (1993), p.300

Malone, T. W., Modeling coordination in organizations and markets, Management science, Vol.10, No.33 (1987), pp. 1317-1332.

野中郁次郎, 竹内弘高, 梅本勝博, 知識創造企業 (1996), p.401, 東洋経済新報社.

Polanyi, M., Tacit knowing: Its bearing on some problems of philosophy, Reviews of modern physics, Vol. 34, No.4 (1962), pp.601-616.

鈴木陽一郎, 金雁, 小山秀夫, 石田修一, シミュレーションによるサービスビジネスプロセス評価のためのモデリ ング手法, 第4 1 回 日本経営システム学会 全国研究発表大会論文集 (2008), pp.76-79.

鈴木陽一郎, 小山秀夫, 金雁, 姜嘉禧, 3101 シミュレーションによる製品・機能ベースプロセスの性能評価, 設計 工学・システム部門講演会講演論文集, Vol.2009, No.19 (2009), pp. 595-599.

Suzuki, Y., Yahyaei, M., Jin, Y., Koyama, H. and Kang, G., An application of simulation based process design, Proceedings of 17th ISPE International conference on concurrent engineering (2010), pp.63-70.

Suzuki, Y., Yahyaei, M., Jin, Y., Koyama, H. and Kang, G., Simulation based process design: Modeling and applications, Advanced engineering informatics, Vol.26, No.4 (2012), pp.763-781.

玉井尚文，司恭彦，技能技術伝承のための新手法，特集新しい方法第 3 章 技術・技能伝承，日本船舶海洋工学会， Vol.6 (2006), pp. 56-63.

Thompson, J. D., Organizations in action: Social science bases of administrative theory (1967), Transaction pub, p.192.

綿貫啓一，小島一恭，没入型 VR システムによる鋳造方案の教育支援，日本機械学会論文集 C 編, Vol.73, No.725 (2007), pp.44-52.

Weber, M., The theory of social and economic organization, Free press (1997), p.448.

Yahyaei, .M., Suzuki, Y. and Jin, Y., DETC2009-87117 PMT: Modeling enterprise operations and organizations, Proceedings of the ASME design engineering technical conferences, 29th Computers and information in engineering conference; DETC2009, 2b (2009), pp. 1061-1074.

\section{References}

Baligh, H. H. and Damon, W. W., Foundation for a systemic process of organization structure design, Journal of information optimization science, Vol.1, No.2 (1980), pp. 133-165. 
Baligh, H. H. and Burton, R. M., Describing and designing organizational structures and processes, International journal of policy analysis information systems, Vol. 5, No. 4 (1982), pp. 251-266.

Fukuda, S. and Niwa, R., Development of scraping skill transfer system using distance learning approach, Transaction of the Japan society of mechanical engineers series C, Vol.72, No.716 (2006), pp.1285-1290 (in Japanese).

Galbraith, J., Organization design (1977), Addison-wesley, p.426.

Hiekata, K., Naito, N., Yamato, H., Ando, H. and Nakazawa, T., A study on knowledge transfer system in shipbuilding : Knowledge acquisition support system, Journal of the Japan society of naval architects and ocean engineers, Vol. 2 (2005), pp.131-137 (in Japanese).

Hiekata, K., Yamato, H., Oishi, W. and Nakazawa, T., Ship design workflow management by ShareFast, Journal of ship production, Vol. 23, No. 1 (2007), pp.23-29.

Lawrence, P. R. and Lorsch, J. W., Organization and environment, Harvard business press (1967), p.296.

March, J. G. and Simon, H. A., Organizations, John wiley \& sons (1993), p.300.

Malone, T. W., Modeling coordination in organizations and markets, Management science, Vol.10, No.33 (1987), pp. 1317-1332.

Nonaka, I., Takeuchi, H. and Umemoto, K., The knowledge creating company (1996), Toyo kezai Inc, p.401 (in Japanese).

Polanyi, M., Tacit knowing: Its bearing on some problems of philosophy, Reviews of modern physics, Vol. 34, No.4 (1962), pp.601-616.

Suzuki, Y., Jin, Y., Koyama, H. and Ishida, S., Service process modeling (A simulation based approach), Proceedings of the 41st annual conference of Japan association for management systems, Vol.2008, No.41 (2008), pp.76-79 (in Japanese).

Suzuki, Y., Koyama, H., Jin, Y. and Kang, G., 3101 Performance evaluation of product/function based design process : A simulation based approach, Proceedings of 19th the Japan society of mechanical engineers. Design \& systems division conference, Vol.2009, No.19 (2009), pp. 595-599 (in Japanese).

Suzuki, Y., Yahyaei, M., Jin, Y., Koyama, H. and Kang, G., An application of simulation based process design, Proceedings of 17th ISPE international conference on concurrent engineering (2010), pp.63-70.

Suzuki, Y., Yahyaei, M., Jin, Y., Koyama, H. and Kang, G., Simulation based process design: Modeling and applications, Advanced engineering informatics, Vol.26, No.4 (2012), pp.763-781.

Tamai, N. and Tsukasa, Y., New method for transferring skills and techniques, Journal of the Japan society of naval architects and ocean engineers, Vol.6 (2006), pp. 56-63 (in Japanese).

Thompson, J. D., Organizations in action: Social science bases of administrative theory (1967), Transaction pub, p.192.

Watanuki, K. and Kojima, K., An educational support for casting design using immersive virtual environment, Transaction of the Japan society of mechanical engineers series C, Vol.73, No.725 (2007), pp.44-52 (in Japanese).

Weber, M., The theory of social and economic organization, Free press (1997), p.448.

Yahyaei, .M., Suzuki, Y. and Jin, Y., DETC2009-87117 PMT: Modeling enterprise operations and organizations, Proceedings of the ASME design engineering technical conferences, 29th Computers and information in engineering conference; DETC2009, 2b (2009), pp. 1061-1074. 